\title{
Exploring atmospheric blocking with GPS radio occultation observations
}

\author{
Lukas Brunner ${ }^{1,2}$, Andrea K. Steiner ${ }^{1,2,3}$, Barbara Scherllin-Pirscher ${ }^{1,3}$, and Martin W. Jury ${ }^{1}$ \\ ${ }^{1}$ Wegener Center for Climate and Global Change (WEGC), University of Graz, Graz, Austria \\ ${ }^{2}$ FWF-DK Climate Change, University of Graz, Graz, Austria \\ ${ }^{3}$ Institute for Geophysics, Astrophysics, and Meteorology, Institute of Physics, University of Graz, Graz, Austria \\ Correspondence to: Lukas Brunner (lukas.brunner@uni-graz.at)
}

Received: 9 October 2015 - Published in Atmos. Chem. Phys. Discuss.: 21 December 2015

Revised: 18 March 2016 - Accepted: 24 March 2016 - Published: 13 April 2016

\begin{abstract}
Atmospheric blocking has been closely investigated in recent years due to its impact on weather and climate, such as heat waves, droughts, and flooding. We use, for the first time, satellite-based observations from Global Positioning System (GPS) radio occultation (RO) and explore their ability to resolve blocking in order to potentially open up new avenues complementing models and reanalyses. RO delivers globally available and vertically highly resolved profiles of atmospheric variables such as temperature and geopotential height (GPH). Applying a standard blocking detection algorithm, we find that RO data robustly capture blocking as demonstrated for two well-known blocking events over Russia in summer 2010 and over Greenland in late winter 2013. During blocking episodes, vertically resolved GPH gradients show a distinct anomalous behavior compared to climatological conditions up to $300 \mathrm{hPa}$ and sometimes even further up into the tropopause. The accompanying increase in GPH of up to $300 \mathrm{~m}$ in the upper troposphere yields a pronounced tropopause height increase. Corresponding temperatures rise up to $10 \mathrm{~K}$ in the middle and lower troposphere. These results demonstrate the feasibility and potential of RO to detect and resolve blocking and in particular to explore the vertical structure of the atmosphere during blocking episodes. This new observation-based view is available globally at the same quality so that blocking in the Southern Hemisphere can also be studied with the same reliability as in the Northern Hemisphere.
\end{abstract}

\section{Introduction}

Weather and climate in the Northern Hemisphere (NH) midlatitudes are dominated by large-scale circulations of the atmosphere and ocean and by dynamical features including jet streams, storm tracks, and blocking. Blocking describes an atmospheric situation where a persistent and stationary high-pressure system blocks the climatological westerly flow for several days to weeks (Rex, 1950). It is often associated with anomalous weather patterns and extreme events (see, e.g., Cattiaux et al., 2010; Matsueda, 2011; Mattingly et al., 2015). The blocking over Russia in summer 2010, for instance, was one of the strongest blocking events in recent history, with impacts on large parts of Europe and Asia. It did not only lead to record-breaking temperatures in Russia but has also been associated with severe flooding in Pakistan at the same time (Matsueda, 2011; Galarneau Jr. et al., 2012). Severe impacts of these blocking-related extremes on society and the economy have increased the interest in investigating blocking evolution and impacts of climate change on blocking frequency and duration (Sillmann et al., 2011; Cohen et al., 2014; Shepherd, 2014; Gramling, 2015; Lhotka and Kyselý, 2015).

In the $\mathrm{NH}$, blocking preferentially occurs near the northeastern ends of the Atlantic and Pacific storm tracks (EuroAtlantic blocking and North Pacific blocking, respectively) (Doblas-Reyes et al., 2002; Barriopedro et al., 2010; IPCC, 2013). Blocking is connected to the North Atlantic oscillation and to jet stream variability (see, e.g., Scherrer et al., 2006; Davini et al., 2014a). A connection of blocking to stratospheric phenomena such as sudden stratospheric warming events has been suggested by several authors in the past 
(e.g., Quiroz, 1986; Martius et al., 2009; Woollings et al., 2010; Barriopedro and Calvo, 2014). Recently, thermodynamic processes in the troposphere such as latent heating have also been found to be important for the formation of blocking (Pfahl et al., 2015).

In the Southern Hemisphere ( $\mathrm{SH}$ ) where the midlatitudes are mostly characterized by oceanic regions with very sparse human population, blocking has received less attention. Main blocking regions are located in the Australia-New Zealand area and in the southeast Pacific (Lejenäs, 1984; Mendes et al., 2008). The frequency and location of SH blocking are strongly influenced by the El Niño-Southern Oscillation (ENSO) and the southern annular mode (Wiedenmann et al., 2002; Oliveira et al., 2014). However, sparse coverage by classical observational systems in the SH introduces larger uncertainties into SH blocking research (Tibaldi et al., 1994; Marques and Rao, 2000).

Most blocking studies are based on climate model output or reanalysis data analyzing geopotential height (GPH) fields at a constant pressure level (see, e.g., Barriopedro et al., 2006, 2010; Barnes et al., 2014; Davini et al., 2014b). Other studies employed dynamical atmospheric parameters such as vertically averaged potential vorticity or potential temperature in the dynamical tropopause (e.g., Pelly and Hoskins, 2003; Schwierz et al., 2004). However, it has been shown that the blocking frequency exhibits considerable inter-model spread in current climate models (Anstey et al., 2013; IPCC, 2013) and blocking trends can differ depending on the reanalysis used (Barnes et al., 2014).

We use, for the first time, observations from Global Positioning System (GPS) radio occultation (RO) to detect blocking and inspect the atmospheric structure during blocking events. This study does not provide an analysis of blocking dynamics nor an extended comparison to model or reanalysis data. Our objective is to explore the feasibility of detecting blocking and to characterize its three-dimensional structure with RO observations. To this end we show blocking patterns and the vertically resolved structure of the troposphere and lower stratosphere during two well-known blocking events: the blocking over Russia in summer 2010 and the blocking over Greenland in winter 2013.

\section{Radio occultation data}

The analysis presented here is based on RO measurements. RO is a satellite-based limb sounding technique, delivering profiles of atmospheric parameters with global coverage and high vertical resolution of about $100 \mathrm{~m}$ in the troposphere to $1.5 \mathrm{~km}$ in the stratosphere (Kursinski et al., 1997; Gorbunov et al., 2004). The horizontal resolution ranges from about 60 to $300 \mathrm{~km}$ (Kursinski et al., 1997). RO data are of high quality. In the troposphere the accuracy of GPH is about $10 \mathrm{~m}$ and that of temperature is better than $1 \mathrm{~K}$ (Scherllin-Pirscher et al., 2011b), with averaged profiles exhibiting further sta- tistical reduction of errors (Scherllin-Pirscher et al., 2011a). Structural uncertainty is low and data from different satellites are highly consistent and require no inter-satellite calibration (Foelsche et al., 2011; Ho et al., 2012; Steiner et al., 2013).

RO data are of great benefit for improving weather forecasts and atmospheric analyses (note that several weather prediction centers already assimilate RO data) as well as for monitoring atmospheric climate variability and changes (see, e.g., Anthes, 2011; Steiner et al., 2011; Gleisner et al., 2015; Randel and $\mathrm{Wu}, 2015)$. RO has been applied, so far, for a range of atmospheric dynamics studies, such as investigating the planetary boundary layer (e.g., von Engeln et al., 2005) and tropopause (Schmidt et al., 2008; Rieckh et al., 2014; Peevey et al., 2014), the ENSO (Scherllin-Pirscher et al., 2012; Sun et al., 2014), atmospheric tides (e.g., Pirscher et al., 2010), and waves, including the Quasi-Biennial Oscillation (Randel et al., 2003; Schmidt et al., 2005), Kelvin waves (e.g., Randel and Wu, 2005), and stratospheric gravity waves (e.g., de la Torre and Alexander, 2005; Tsuda, 2014). Recent studies also focused on tracing wind fields (ScherllinPirscher et al., 2014) and analyzing the thermodynamic structure of cyclones (Biondi et al., 2015).

$\mathrm{RO}$ data used in the present study were processed with the Wegener Center occultation processing system version 5.6 (OPSv5.6) (Schwärz et al., 2013). The full set of atmospheric variables derived from RO includes density, pressure, GPH, temperature, potential temperature, and tropospheric water vapor. Observations from several RO missions are exploited including from the CHAllenging Minisatellite Payload (CHAMP), the Gravity Recovery and Climate Experiment (GRACE), and the Constellation Observing System for Meteorology, Ionosphere, and Climate (COSMIC) for the period 2006 to 2013, where we focus on two wellknown blocking events: over Russia in summer 2010 (Russian blocking) and over Greenland in late winter and early spring 2013 (Greenland blocking). During these time periods about 800 high-quality RO profiles are available per day in the $\mathrm{NH}$.

We analyze GPH and temperature profiles as a function of pressure. The levels of the pressure grid have been calculated from $p_{i}\left(z_{i}\right)=p_{0} \exp \left(-\frac{z_{i}}{H}\right)$, with $p_{0}=1013.25 \mathrm{hPa}$ (standard surface pressure), $H=7000 \mathrm{~m}$ (constant scale height), and altitude $z_{i}$ ranging from the surface to $16 \mathrm{~km}$ (corresponding to about $100 \mathrm{hPa}$ ) in equidistant $200 \mathrm{~m}$ steps.

We calculate daily fields on a $2.5^{\circ} \times 2.5^{\circ}$ longitudelatitude grid by applying a weighted average to the RO profiles:

$x_{\text {grid }}(\lambda, \phi, d)=\frac{\sum_{i} w_{i} x_{i}\left(\lambda^{\prime}, \phi^{\prime}, d^{\prime}\right)}{\sum_{i} w_{i}}$,

where $x_{\text {grid }}(\lambda, \phi, d)$ is GPH or temperature at a specific grid point at longitude $\lambda$, latitude $\phi$, and day $d . x_{i}\left(\lambda^{\prime}, \phi^{\prime}, d^{\prime}\right)$ denotes an individual atmospheric profile at the RO event location $\left(\lambda^{\prime}, \phi^{\prime}\right)$ and day $\left(d^{\prime}\right)$. All RO events within $\pm 7.5^{\circ}$ in longitude, $\pm 2.5^{\circ}$ in latitude, and \pm 2 days are considered and 
weighted with a Gaussian weighting function $w_{i}$ over longitude and time according to $w_{i}=\exp \left(-\left[\left(\frac{\Delta \lambda}{L}\right)^{2}+\left(\frac{\Delta d}{D}\right)^{2}\right]\right)$, with $L=7.5^{\circ}$ and $D=1$ day (adapted from Randel and $\mathrm{Wu}$, 2005). This effective resolution has been chosen to minimize the number of bins in which no measurements exist, while still resolving most of the atmospheric variability. Sensitivity tests with data from the European Centre for Medium-range Weather Forecasts (ECMWF) reanalysis Interim (ERA-Interim) (Dee et al., 2011) showed only small differences $(<100 \mathrm{~m}$ in geopotential height) between mean fields obtained from this binning and native $2.5^{\circ} \times 2.5^{\circ}$ daily fields, confirming the robustness of our gridding strategy.

Figures $1 \mathrm{a}$ and $2 \mathrm{a}$ depict the distribution of RO profiles and the number of profiles contributing to each grid cell for 2 exemplary days during the Russian blocking in 2010 and the Greenland blocking in 2013. More than $80 \%$ of all grid cells contain information of at least four RO profiles. Only near the equator and at very high latitudes does the number of profiles decrease, and some grid cells with no measurements exist.

Applying our gridding method, we are able to resolve synoptic-scale atmospheric variability on a daily basis as shown for GPH at the $500 \mathrm{hPa}$ pressure level (Figs. 1b and $2 b$ ). At midlatitudes (between approximately 45 and $65^{\circ} \mathrm{N}$ ), mean GPH fields reveal high-pressure systems over Scandinavia and the western part of Russia in summer 2010 (Russian blocking) and over the east Atlantic in winter and spring 2013 (Greenland blocking), representing typical blocking situations (Davini et al., 2014a).

These features are even more pronounced in GPH anomaly fields (Figs. 1c and 2c) which are calculated relative to the daily means averaged over 8 years (2006 to 2013). GPH anomalies are larger during the Greenland blocking $(>300 \mathrm{~m})$ in winter than during the Russian blocking (mainly within $200 \mathrm{~m}$ ) in summer. However, both anomalies are distinctively larger than the variability, shown as the standard deviation of the individual RO profiles in each grid cell in Figs. 1d and 2d for the Russian and Greenland blocking, respectively.

To provide information about uncertainty associated with discrete data sampling and our averaging method, Figs. 1e and $2 \mathrm{e}$ show the sampling error (SE). It is calculated as the difference between the mean field from co-located ECMWF analysis profiles applying the same averaging technique as for RO profiles (see above) and the daily mean ECMWF analysis field on a native $2.5^{\circ} \times 2.5^{\circ}$ resolution. For both blocking events, the SE is distinctively smaller than the GPH anomalies. It is slightly larger during the Greenland blocking than during the Russian blocking because (i) atmospheric variability is stronger in the winter season than in the summer season and (ii) the number of profiles is slightly smaller in 2013 than in 2010. However, the small magnitude of the SE (Figs. 1e and 2e) compared to blocking-related anomalies (Figs. 1c and 2c) as well as small standard deviation (Figs. 1d and $2 \mathrm{~d}$ ) underpins the fact that RO data sampling is sufficient to capture atmospheric variability on a daily basis when applying a suitable averaging technique. RO data are therefore well suited for blocking detection.

\section{Blocking detection}

Blocking diagnosis is usually performed on a fixed pressure level (see, e.g., Barriopedro et al., 2006, 2010; Barnes et al., 2014; Davini et al., 2014b). To detect blocking episodes we utilize a frequently used blocking index based on GPH at $500 \mathrm{hPa}$ (Tibaldi and Molteni, 1990; Scherrer et al., 2006; Davini et al., 2012, 2014b). Blocking is identified via three criteria.

First, the northern and southern GPH gradients, $\Delta Z_{N}$ and $\Delta Z_{\mathrm{S}}$, are calculated as

$\Delta Z_{\mathrm{N}}(\lambda, \phi, p)=\frac{Z(\lambda, \phi+\Delta \phi, p)-Z(\lambda, \phi, p)}{\Delta \phi}$,
$\Delta Z_{\mathrm{S}}(\lambda, \phi, p)=\frac{Z(\lambda, \phi, p)-Z(\lambda, \phi-\Delta \phi, p)}{\Delta \phi}$,

where $\Delta \phi=15^{\circ}$. The computation is performed separately for each $2.5^{\circ} \times 2.5^{\circ}$ grid point from 50 to $65^{\circ} \mathrm{N}$; thus, grid points are effectively used from 35 to $80^{\circ} \mathrm{N}$ over all longitudes. Following Davini et al. (2014a), instantaneous blocking $(I B)$ is identified if both of the following conditions are met: $\Delta Z_{\mathrm{S}}\left(\lambda, \phi, p^{\prime}\right)>0 \mathrm{~m} /{ }^{\circ}$ lat and $\Delta Z_{\mathrm{N}}\left(\lambda, \phi, p^{\prime}\right)$ $<-10 \mathrm{~m} /{ }^{\circ}$ lat at $p^{\prime}=500 \mathrm{hPa}$. A positive southward gradient indicates the reversal of the meridional GPH gradient with easterlies equatorward of $\phi$. This is the essential condition for blocking. Additionally, the second condition indicates strong westerlies poleward of $\phi$. It rules out some synoptic cases which marginally satisfy condition one but are not blockings (Tibaldi and Molteni, 1990; Anstey et al., 2013).

The second blocking detection criterion is set to account only for large high-pressure systems. Thus, extended IB is identified at a grid point if all neighboring grid cells within $\pm 7.5^{\circ}$ longitude are instantaneously blocked.

The third criterion guarantees detecting only stationary high-pressure systems and filtering out fast-moving events. It specifies that a grid cell with extended IB is blocked if at least one grid cell with extended IB is found within a box of $10^{\circ}$ longitude $\times 5^{\circ}$ latitude on each of the neighboring \pm 2 days.

Figure 3 shows the blocking occurrence and temporal evolution at the $500 \mathrm{hPa}$ pressure level for the Russian and Greenland blocking. To demonstrate the influence of the three blocking criteria, Fig. 3 also includes IB and extended IB. Note the very similar patterns for all criteria, indicating that the gradient criterion (first criterion) is in principle sufficient for catching most of the blocking features.

Overall, the evolutions of the blocking patterns are different for the Russian blocking and the Greenland blocking. While the Russian blocking is more continuous, lasting for more than 6 weeks from the end of June to mid-August, the Greenland blocking is most pronounced only for about 

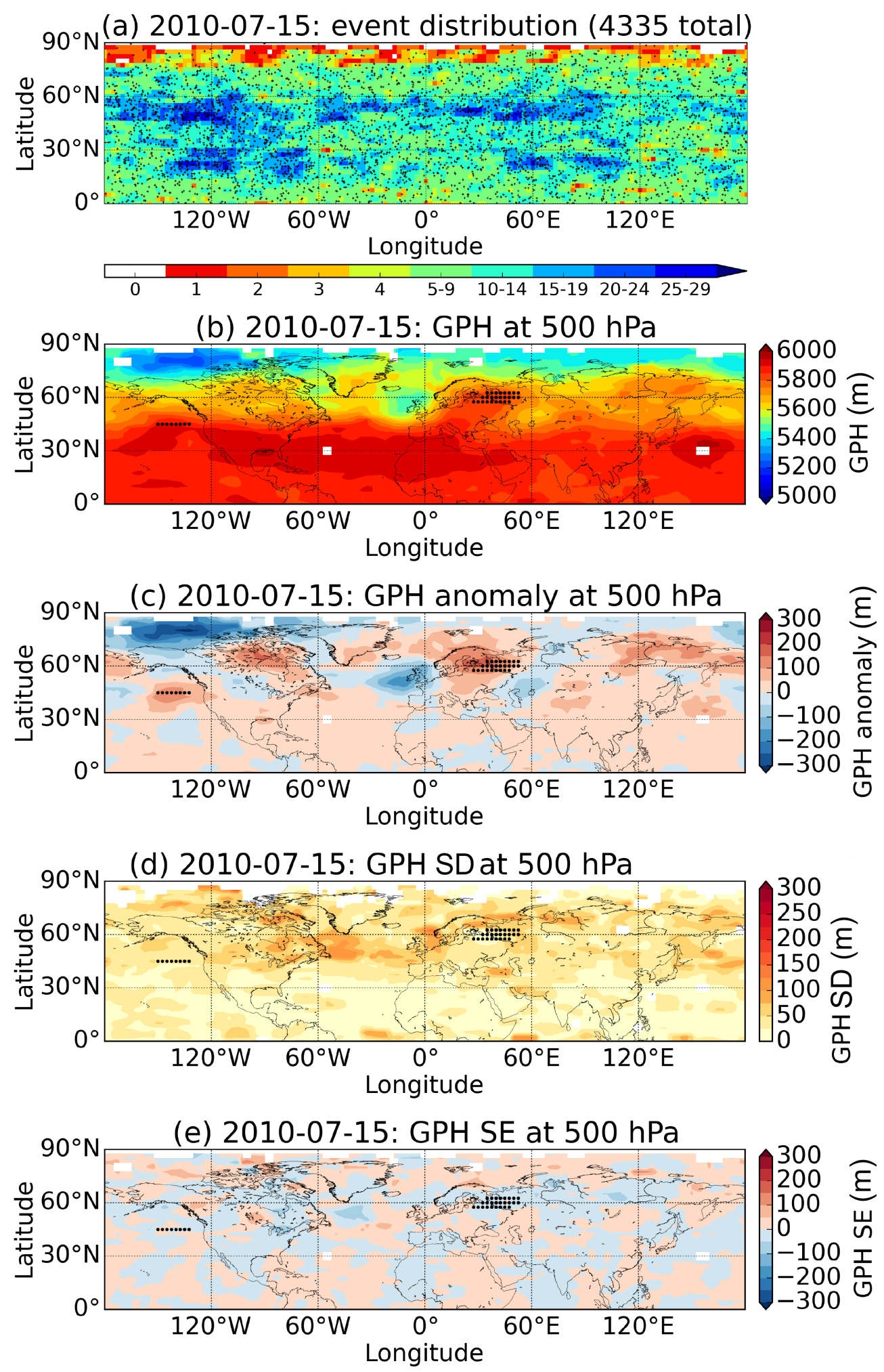

Figure 1. Panel (a): RO event distribution (plus signs) in the NH for an exemplary day ( \pm 2 neighboring days) during the Russian blocking and number of events per grid cell (shading). Other panels: geographic maps at $500 \mathrm{hPa}$ of (b) GPH, (c) GPH anomaly relative to the mean from 2006 to 2013, (d) standard deviation of individual profiles, and (e) sampling error. Blocked grid cells are indicated by dots; missing data are white. 

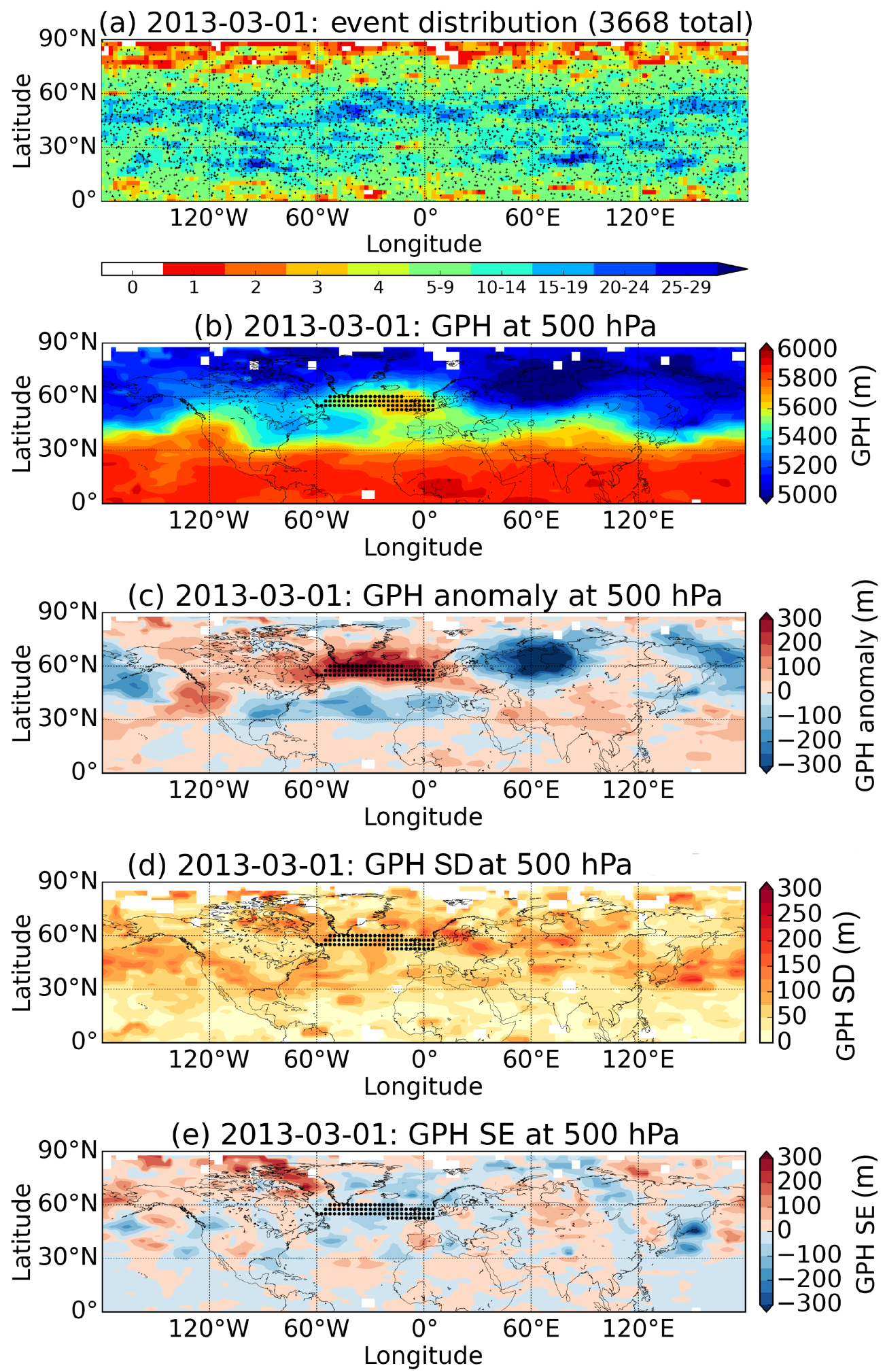

Figure 2. Same layout as Fig. 1 but for an exemplary day during the Greenland blocking. 

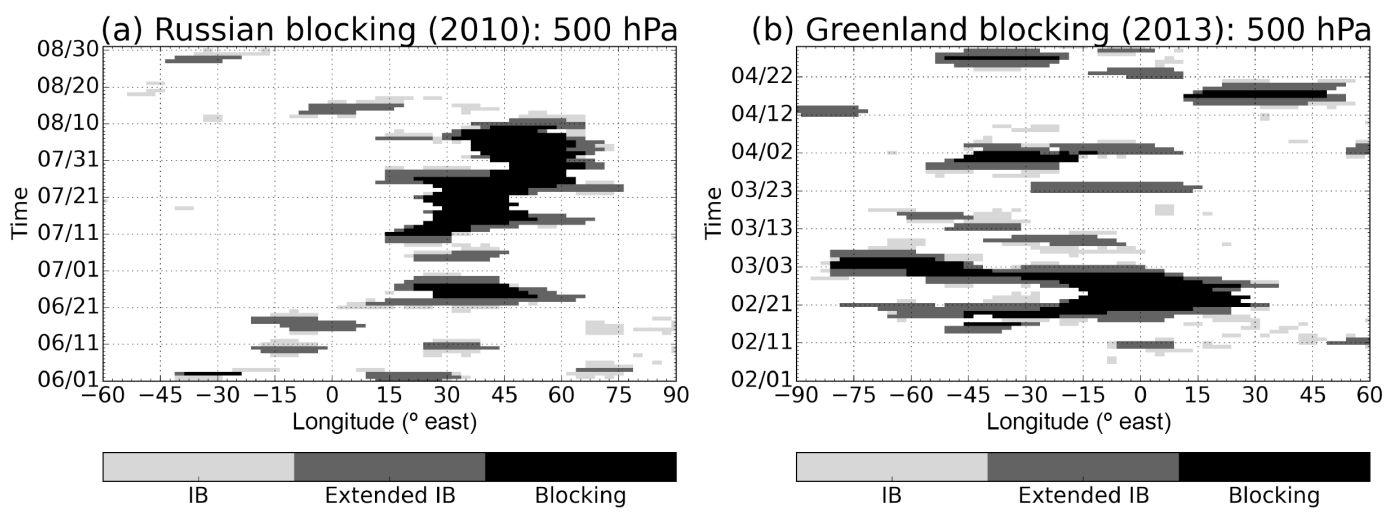

Figure 3. Hovmöller diagrams of observed blocking occurrence at $500 \mathrm{hPa}$ over (a) Russia in June-July-August (JJA) 2010 and over (b) Greenland in February-March-April (FMA) 2013. Blocking is considered between 50 and $65^{\circ}$ N. Shading indicates the three blocking detection steps: IB (light gray), extended IB (dark gray), and blocking (black).

2 weeks from mid-February to early March, with minor and less extended blockings taking place until mid-April 2013. The Russian blocking is smaller in longitudinal extent, ranging over $55^{\circ}$, while the Greenland blocking is twice as large, ranging over $100^{\circ}$ in longitude.

We compared the resulting blocking patterns from RO observations to those from ERA-Interim data and found very good agreement (Brunner et al., 2015). The consistency of our results is also confirmed by comparison with existing literature (see, e.g., Matsueda, 2011, Fig. 1b). This again proves the feasibility of blocking detection with RO.

\section{Vertically resolved blocking patterns}

Tropospheric profiles of GPH gradients are shown in Fig. 4 for 2 exemplary days and regions for the Russian and Greenland blocking, respectively. Climatological GPH gradients in the same region are additionally shown for comparison. These climatological gradients $\Delta Z_{S}$ and $\Delta Z_{N}$ for JuneJuly-August (JJA) and February-March-April (FMA) are obtained from averaging over all available years (2006 to 2013).

During normal, climatological conditions (Fig. 4a, b), all gradient profiles are close to each other. In the entire troposphere above the boundary layer GPH gradients are smaller than $0 \mathrm{~m} /{ }^{\circ}$ lat indicating the climatological westerly geostrophic flow at NH midlatitudes. In general, the climatological northern gradients are near to the blocking threshold $\left(-10 \mathrm{~m} /{ }^{\circ}\right.$ lat $)$. For the inspected regions they are even found below the threshold.

A clear separation between the northern and southern gradients can be observed during blocking events as presented for 2 exemplary days and regions for the Russian and Greenland blocking, respectively (Fig. 4c, d). While the southern gradient becomes positive (i.e., easterly geostrophic flow equatorward of the depicted region), the northern gradient becomes distinctively more negative compared to the clima- tology: at $500 \mathrm{hPa} \Delta Z_{\mathrm{N}}$ exceeds $-20 \mathrm{~m} /{ }^{\circ}$ lat over Russia in July and even $-30 \mathrm{~m} /{ }^{\circ}$ lat over Greenland in March, further increasing upwards. Figure $4 \mathrm{c}$ also shows some $\Delta Z_{\mathrm{S}}$ profiles which do not reach the IB criterion at some grid cells within the depicted region. However, the all-mean gradients $\Delta Z_{\mathrm{S}}$ and $\Delta Z_{\mathrm{N}}$ clearly represent instantaneously blocked conditions during these particular days.

The corresponding evolution of the GPH gradients over time is shown in Fig. 5 for exemplary grid cells during the Russian and Greenland blocking. Different temporal and vertical behavior of $\Delta Z_{\mathrm{N}}$ (Fig. 5a, b) and $\Delta Z_{\mathrm{S}}$ (Fig. 5c, d) is evident. $\Delta Z_{\mathrm{N}}$ is always negative in JJA 2010 and meets the IB criterion during almost the entire period. During some days in February and March 2013, however, it is positive in the entire troposphere, indicating a potential high-pressure system at high northern latitudes ( 70 to $75^{\circ} \mathrm{N}$ ). In JJA 2010, the southern gradient is positive for a couple of days by the end of June 2010 and for a longer time period from mid-July to mid-August 2010. In FMA 2013, positive $\Delta Z_{\mathrm{S}}$ can be found for several days from mid-February to early March 2013 as well as for some days in early April 2013.

The comparison of the northern and the southern gradient and their combined use for IB detection based on the two blocking cases reveals that the $\Delta Z_{\mathrm{S}}$ criterion is harder to meet than the $\Delta Z_{\mathrm{N}}$ criterion, in particular during JJA 2010. During this time period two IB episodes can be identified over Russia: a short one at the end of June 2010 and a more persistent one from mid-July to mid-August 2010. Over Greenland, IB is found for mid-February to early March 2013 as well as for 3 days in early April 2013. Note that IB periods that are too short will no longer appear as blocking since additional blocking criteria become effective. Overall, blocking episodes show a distinct vertical extent of the GPH gradient up to $300 \mathrm{hPa}$ (Russia) and even up to the tropopause at about $200 \mathrm{hPa}$ (Greenland). Outside blocked episodes the gradients mainly show climatological behavior. 
(a) JJA, $40^{\circ} \mathrm{E}-50^{\circ} \mathrm{E}, 55^{\circ} \mathrm{N}-60^{\circ} \mathrm{N}$ : GPH gradients

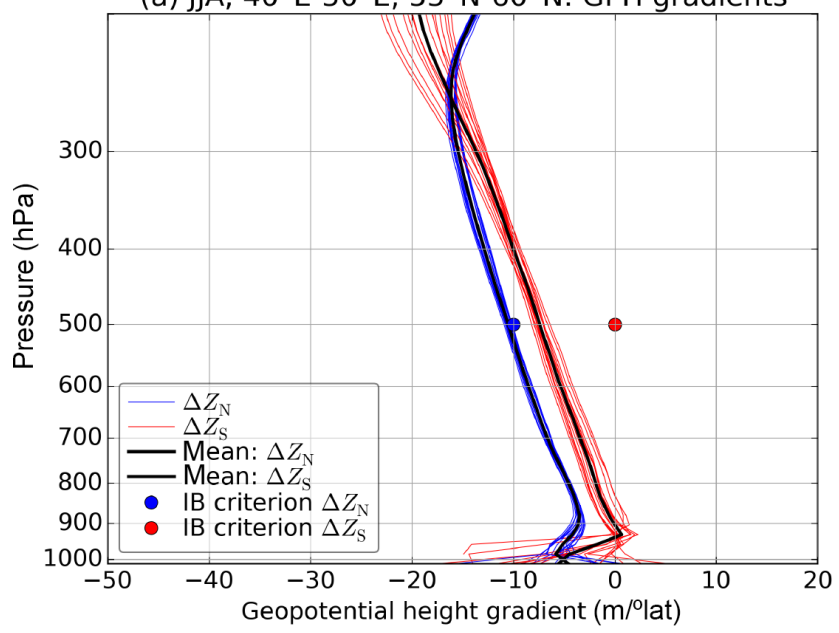

(c) $2010-07-15,40^{\circ} \mathrm{E}-50^{\circ} \mathrm{E}, 55^{\circ} \mathrm{N}-60^{\circ} \mathrm{N}$ : GPH gradients

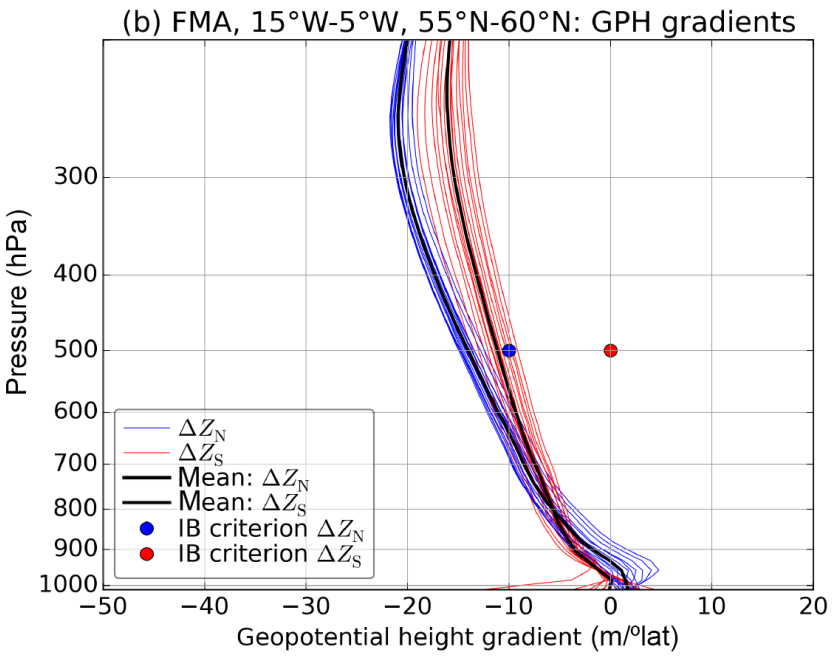

(d) $2013-03-01,15^{\circ} \mathrm{W}-5^{\circ} \mathrm{W}, 55^{\circ} \mathrm{N}-60^{\circ} \mathrm{N}$ : GPH gradients
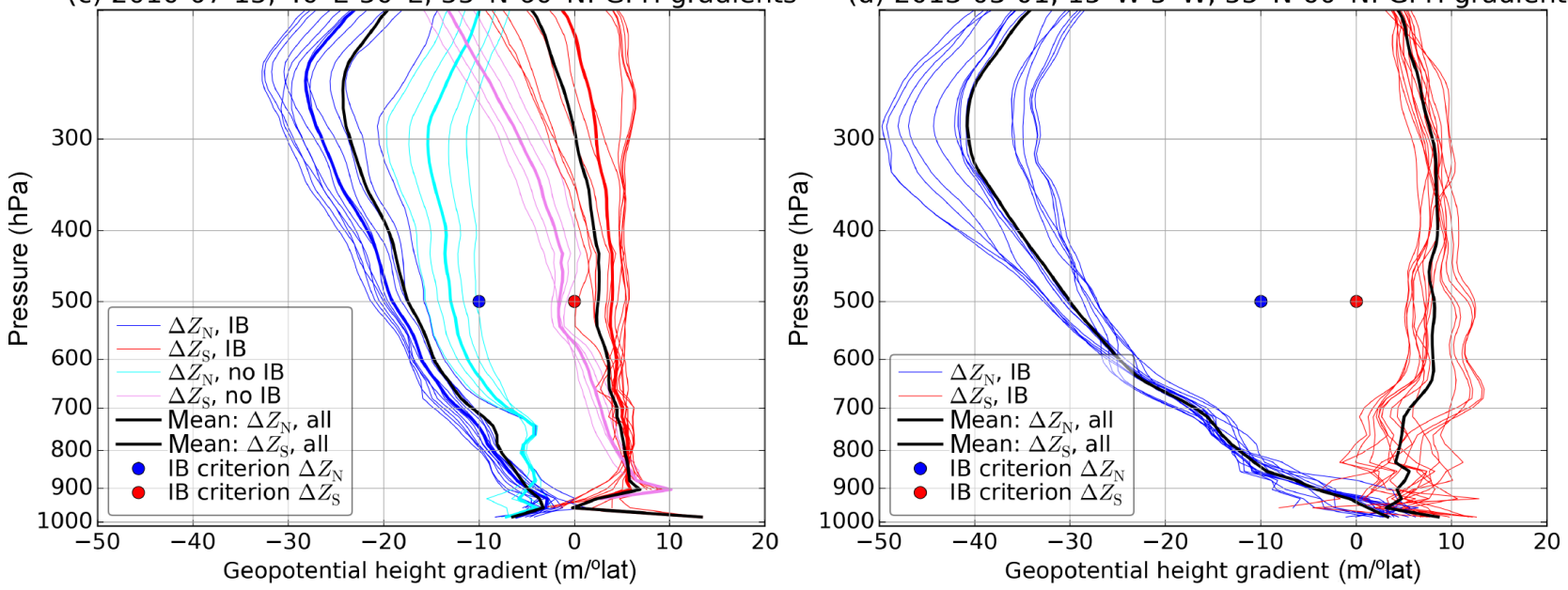

Figure 4. Vertical profiles of (blue) $\Delta Z_{\mathrm{N}}$ and (red) $\Delta Z_{\mathrm{S}}$ during climatological conditions in (a) JJA 2006 to 2013 within 40 to $50^{\circ} \mathrm{E}$ and 55 to $60^{\circ} \mathrm{N}$ and (b) FMA 2006 to 2013 within 15 to $5^{\circ} \mathrm{W}$ and 55 to $60^{\circ} \mathrm{N}$. $\Delta Z_{\mathrm{N}}$ and $\Delta Z_{\mathrm{S}}$ are given for individual grid cells (thin lines) and the respective region mean (bold lines). IB blocking criteria at $500 \mathrm{hPa}$ are shown for $\Delta Z_{\mathrm{N}}$ (blue dot) and $\Delta Z_{\mathrm{S}}$ (red dot). Vertical profiles of GPH gradients for an exemplary day during the (c) Russian blocking and (d) Greenland blocking; same area as (a) and (b), respectively. Blocked profiles (blue, red) and those not meeting the blocking criteria (light blue, light red) are shown, as are mean (bold colored) and all-mean (bold black) $\Delta Z_{\mathrm{N}}$ and $\Delta Z_{\mathrm{S}}$ profiles. Note that the mean is identical with the "all-mean" for the Greenland blocking.

The vertical structure of blocking in GPH and temperature anomalies during the Russian and Greenland blocking is shown in Figs. 6 and 7, respectively. Meridional cross sections reveal the longitudinal extent of blockings with strong positive GPH anomalies during these events (Fig. 6a, b). The different characteristics in their temporal evolution are shown in Fig. $6 c$ and d. Positive GPH anomalies extend into the stratosphere and show a maximum near the tropopause at approximately $200 \mathrm{hPa}$, exceeding 250 to $300 \mathrm{~m}$ during blocking episodes. The height of the lapse-rate tropopause correlates well with GPH maxima and minima. During the persistent Russian blocking, it stays almost constant (Fig. 6c) compared to its usual variations during unblocked conditions. Meridional cross sections of temperature anomalies (Fig. 7a, b) reveal strong positive anomalies in the troposphere during blocking. These correspond to strong positive GPH anomalies and further result in a higher lapse-rate tropopause and in negative temperature anomalies in the stratosphere relative to climatological conditions. Strongest positive temperature anomalies of up to $10 \mathrm{~K}$ are found in the lower troposphere towards the surface during the Russian blocking (Fig. 7c). During the Greenland blocking, maximum temperature anomalies of up to $6 \mathrm{~K}$ are observed in the midtroposphere (Fig. 7d). 

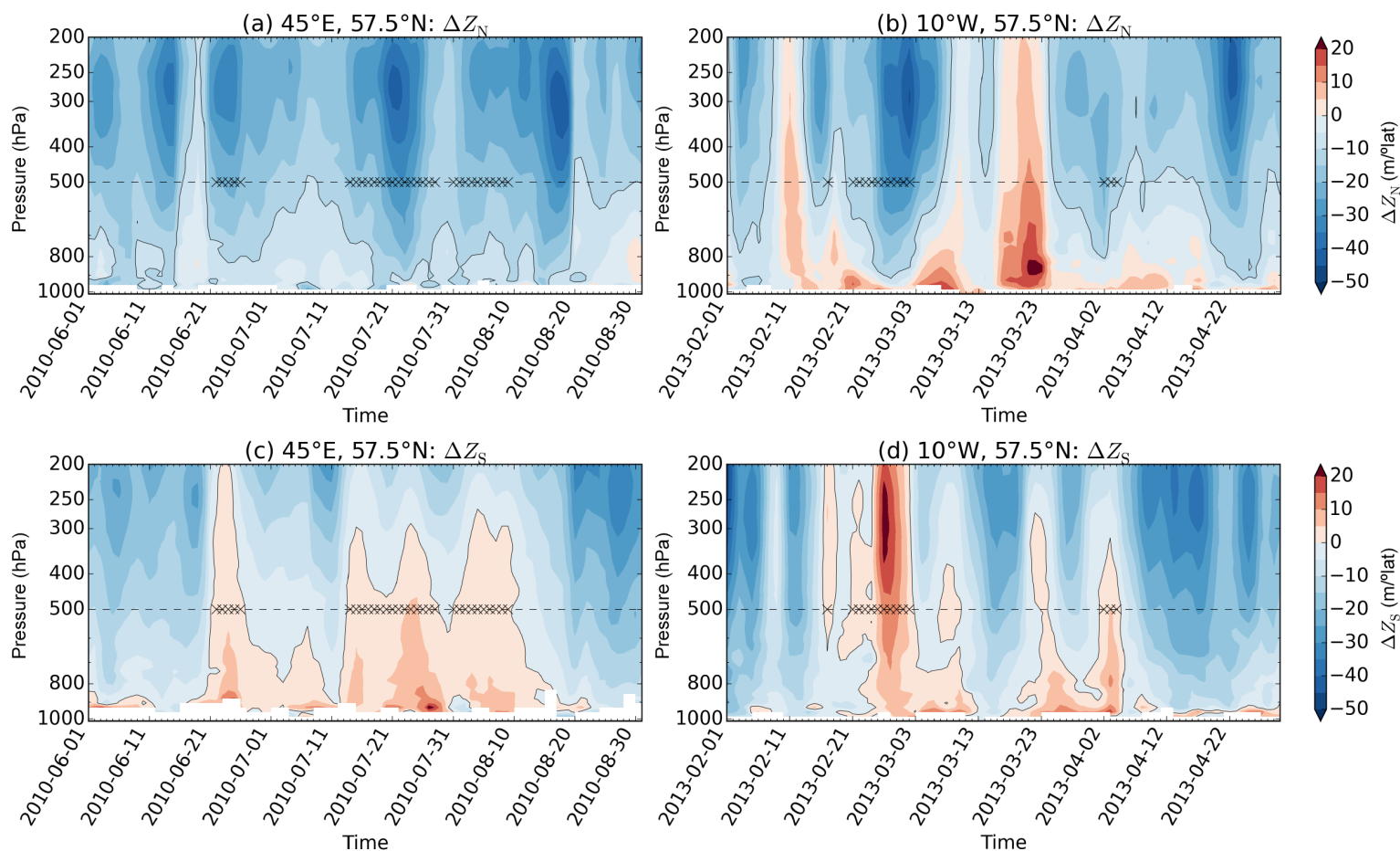

Figure 5. Temporal evolution of $\Delta Z_{\mathrm{N}}$ and $\Delta Z_{\mathrm{S}}$ during the (a, c) Russian and (b, d) Greenland blocking. Blocking criteria (solid black contours) are indicated at $-10 \mathrm{~m} /{ }^{\circ}$ lat for $\Delta Z_{\mathrm{N}}$ and $0 \mathrm{~m} /{ }^{\circ}$ lat for $\Delta Z_{\mathrm{S}}$. IB (crosses) is indicated at the $500 \mathrm{hPa}$ pressure level (dashed black line).
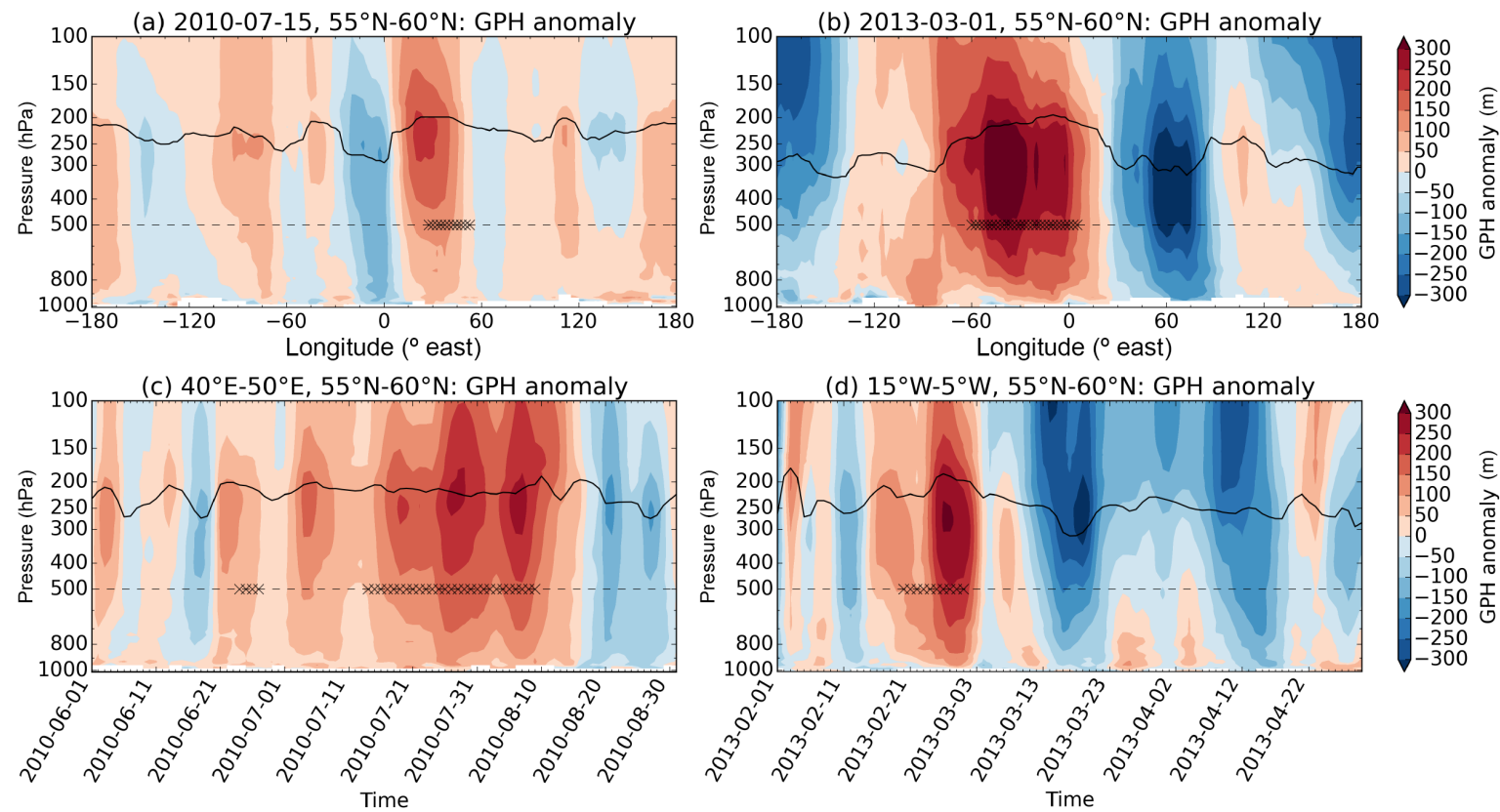

Figure 6. GPH anomalies during (left column) Russian blocking and (right column) Greenland blocking. Panels (a, b): meridional cross sections of GPH for 2 exemplary days and regions as well as (c, d) temporal evolution of GPH for the same regions. Blocking (crosses) at the $500 \mathrm{hPa}$ level (dashed line) is indicated if at least one grid cell in the averaged area is blocked. The solid line denotes the lapse-rate tropopause. 

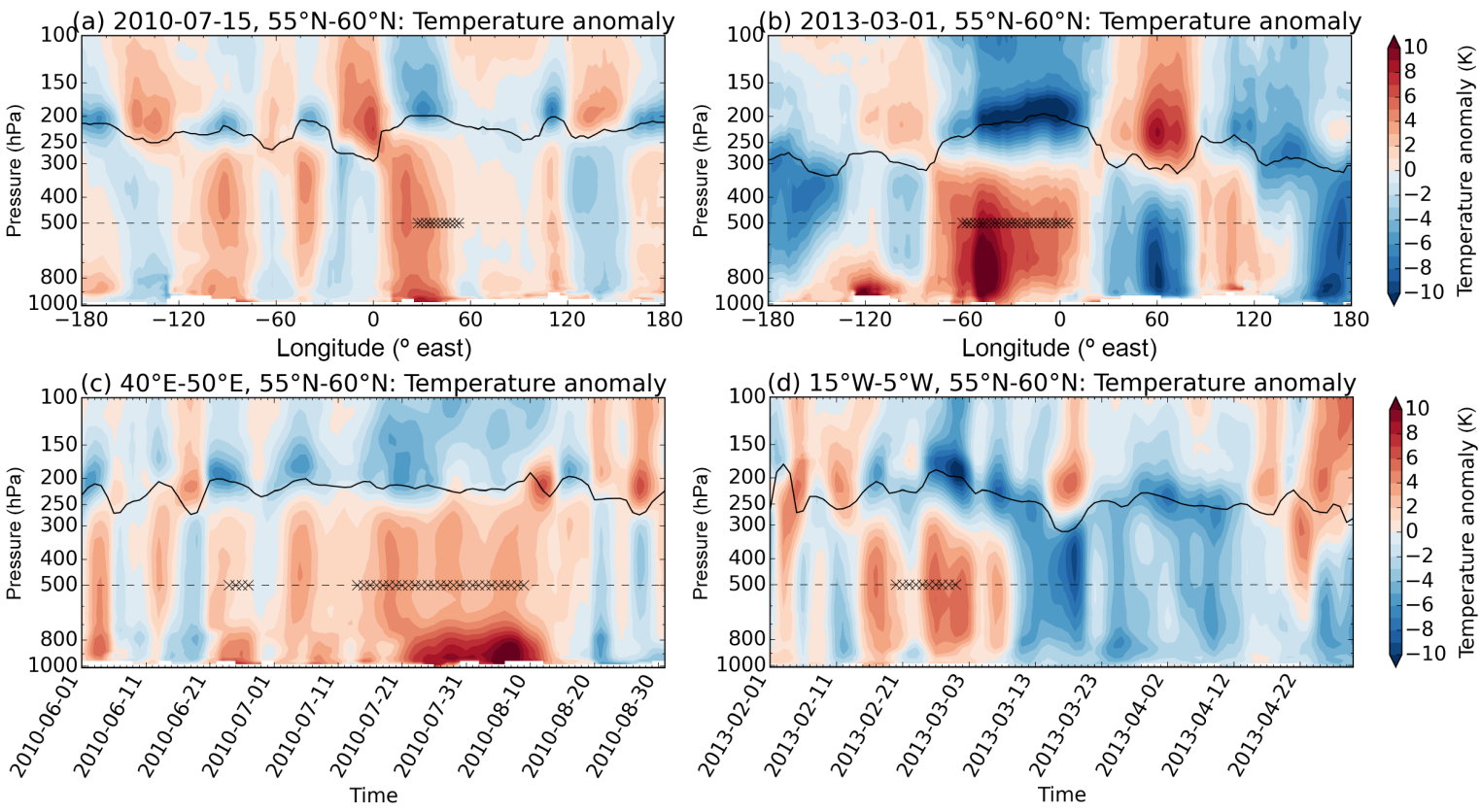

Figure 7. Same layout as Fig. 6 but for temperature anomalies.

\section{Conclusions}

We demonstrated the feasibility of atmospheric blocking detection in observations from radio occultation (RO). Utilizing about 800 profiles per day in the $\mathrm{NH}$ and applying an adequate gridding strategy, $\mathrm{RO}$ data are found to be dense enough to resolve atmospheric variability reasonably well on a daily basis as shown for geopotential height (GPH) fields and corresponding uncertainty measures.

For blocking detection we utilized a standard blocking detection algorithm based on GPH gradients at the $500 \mathrm{hPa}$ pressure level. We analyzed two well-known blocking events over Russia in summer 2010 and over Greenland in late winter and early spring 2013 . The resulting blocking pattern and temporal evolution in RO fields fully represent the characteristics of the events, consistent with existing literature.

Furthermore, we explored the vertically resolved atmospheric structure during blocking based on tropospheric profiles of GPH gradients. While GPH gradient profiles during climatological conditions are found to be smaller than $0 \mathrm{~m} /{ }^{\circ}$ lat in the entire troposphere above the boundary layer, indicating the westerly geostrophic flow at $\mathrm{NH}$ midlatitudes, a clear separation between the northern and southern gradients is observed during blocking episodes. The southern gradients become positive, indicating an easterly geostrophic flow equatorwards, while the northern gradients become distinctively more negative up to a few $-10 \mathrm{~m} /{ }^{\circ}$ lat, depending on region and season. A distinct vertical extent of these features up to $300 \mathrm{hPa}$ and even up to the tropopause is found.

During blocking, characteristic structures in GPH and temperature anomaly fields are found in the troposphere and

lower stratosphere. Strong positive GPH anomalies of up to $300 \mathrm{~m}$ in the upper troposphere yield a clear tropopause height increase. Corresponding temperature anomalies of up to $10 \mathrm{~K}$ are found in the middle and lower troposphere.

Overall, RO data are found to be very well suited for blocking detection and for providing information on the atmospheric structure during blocking episodes. They allow the detection and analysis of vertically resolved atmospheric blocking patterns in a comprehensive observationbased record and a set of atmospheric variables comprising density, pressure, GPH, temperature, potential temperature, and tropospheric water vapor.

RO observations from constellations such as COSMIC cover the entire Earth and can therefore provide a reliable data basis also in the Southern Hemisphere. They allow for comparisons of the atmospheric characteristics of both hemispheres without being affected by inhomogeneous data coverage. Since RO profiles also sample the lower stratosphere, they can, moreover, provide valuable information about the influence of stratospheric phenomena on blocking. RO could therefore complement ongoing research on the connection between sudden stratospheric warming events and blocking. Furthermore, combining RO observations in the free atmosphere with surface measurements will allow for a better understanding of the evolution of surface impacts, planned for future research.

Acknowledgements. The authors acknowledge ECMWF (Reading, UK) for access to its analysis data and UCAR/CDAAC (Boulder, CO, USA) for access to its RO phase and orbit data. The WEGC processing team members, especially M. Schwärz, are thanked for 
OPSv5.6 RO data provision. RO data used for this study are available at WEGC (via www.wegcenter.at). We thank P. Davini (ISAC, IT), G. Kirchengast (WEGC, AT), and F. Ladstädter (WEGC, AT) for helpful comments and input. This work was funded by the Austrian Science Fund (FWF) under research grants W 1256-G15 (Doctoral Programme Climate Change - Uncertainties, Thresholds and Coping Strategies) and T 620-N29 (DYNOCC). We thank $\mathrm{R}$. Anthes and one anonymous reviewer for their helpful comments and corrections.

Edited by: T. von Clarmann

\section{References}

Anstey, J. A., Davini, P., Gray, L. J., Woollings, T. J., Butchart, N., Cagnazzo, C., Christiansen, B., Hardiman, S. C., Osprey, S. M., and Yang, S.: Multi-model analysis of Northern Hemisphere winter blocking: Model biases and the role of resolution, J. Geophys. Res., 118, 3956-3971, doi:10.1002/jgrd.50231, 2013.

Anthes, R. A.: Exploring Earth's atmosphere with radio occultation: contributions to weather, climate and space weather, Atmos. Meas. Tech., 4, 1077-1103, doi:10.5194/amt-4-1077-2011, 2011.

Barnes, E. A., Dunn-Sigouin, E., Masato, G., and Woollings, T.: Exploring recent trends in Northern Hemisphere blocking, Geophys. Res. Lett., 41, 638-644, doi:10.1002/2013GL058745, 2014.

Barriopedro, D. and Calvo, N.: On the Relationship between ENSO, Stratospheric Sudden Warmings, and Blocking, J. Climate, 27, 4704-4720, doi:10.1175/JCLI-D-13-00770.1, 2014.

Barriopedro, D., García-Herrera, R., Lupo, A. R., and Hernández, E.: A climatology of northern hemisphere blocking, J. Climate, 19, 1042-1063, doi:10.1175/JCLI3678.1, 2006.

Barriopedro, D., García-Herrera, R., and Trigo, R. M.: Application of blocking diagnosis methods to General Circulation Models. Part I: a novel detection scheme, Clim. Dynam., 35, 1373-1391, doi:10.1007/s00382-010-0767-5, 2010.

Biondi, R., Steiner, A. K., Kirchengast, G., and Rieckh, T.: Characterization of thermal structure and conditions for overshooting of tropical and extratropical cyclones with GPS radio occultation, Atmos. Chem. Phys., 15, 5181-5193, doi:10.5194/acp-15-51812015, 2015.

Brunner, L., Steiner, A. K., Scherllin-Pirscher, B., and Jury, M. W.: Feasibility of blocking detection in observations from radio occultation, Geophys. Res. Abstr., EGU2015-1519, EGU General Assembly 2015, Vienna, Austria, 2015.

Cattiaux, J., Vautard, R., Cassou, C., Yiou, P., Masson-Delmotte, V., and Codron, F.: Winter 2010 in Europe: A cold extreme in a warming climate, Geophys. Res. Lett., 37, L20704, doi:10.1029/2010GL044613, 2010.

Cohen, J., Screen, J. A., Furtado, J. C., Barlow, M., Whittleston, D., Coumou, D., Francis, J., Dethloff, K., Entekhabi, D., Overland, J., and Jones, J.: Recent Arctic amplification and extreme mid-latitude weather, Nat. Geosci., 7, 627-637, doi:10.1038/ngeo2234, 2014.

Davini, P., Cagnazzo, C., Gualdi, S., and Navarra, A.: Bidimensional diagnostics, variability, and trends of Northern Hemi- sphere blocking, J. Climate, 25, 6496-6509, doi:10.1175/JCLID-12-00032.1, 2012.

Davini, P., Cagnazzo, C., and Anstey, J. A.: A blocking view of the stratosphere-troposphere coupling, J. Geophys. Res., 119, 11 100-11 115, doi:10.1002/2014JD021703, 2014a.

Davini, P., Cagnazzo, C., Fogli, P. G., Manzini, E., Gualdi, S., and Navarra, A.: European blocking and Atlantic jet stream variability in the NCEP/NCAR reanalysis and the CMCC-CMS climate model, Clim. Dynam., 43, 71-85, doi:10.1007/s00382-0131873-y, 2014b.

de la Torre, A. and Alexander, P.: Gravity waves above Andes detected from GPS radio occultation temperature profiles: Mountain forcing?, Geophys. Res. Lett., 32, L17815, doi:10.1029/2005GL022959, 2005.

Dee, D. P., Uppala, S. M., Simmons, A. J., Berrisford, P., Poli, P., Kobayashi, S., Andrae, U., Balmaseda, M. A., Balsamo, G., Bauer, P., Bechtold, P., Beljaars, A. C. M., van de Berg, L., Bidlot, J., Bormann, N., Delsol, C., Dragani, R., Fuentes, M., Geer, A. J., Haimberger, L., Healy, S. B., Hersbach, H., Hólm, E. V., Isaksen, L., Kållberg, P., Köhler, M., Matricardi, M., McNally, A. P., Monge-Sanz, B. M., Morcrette, J.-J., Park, B.-K., Peubey, C., de Rosnay, P., Tavolato, C., Thépaut, J.-N., and Vitart, F.: The ERA-Interim reanalysis: configuration and performance of the data assimilation system, Q. J. Roy. Meteor. Soc., 137, 553-597, doi:10.1002/qj.828, 2011.

Doblas-Reyes, F. J., Casado, M. J., and Pastor, M. A.: Sensitivity of the Northern Hemisphere blocking frequency to the detection index, J. Geophys. Res., 107, ACL 6-1-ACL 6-22, doi:10.1029/2000JD000290, 2002.

Foelsche, U., Scherllin-Pirscher, B., Ladstädter, F., Steiner, A. K., and Kirchengast, G.: Refractivity and temperature climate records from multiple radio occultation satellites consistent within $0.05 \%$, Atmos. Meas. Tech., 4, 2007-2018, doi:10.5194/amt-4-2007-2011, 2011

Galarneau Jr., T. J., Hamill, T. M., Dole, R. M., and Perlwitz, J.: A Multiscale Analysis of the Extreme Weather Events over Western Russia and Northern Pakistan during July 2010, Mon. Weather Rev., 140, 1639-1664, doi:10.1175/MWR-D-11-00191.1, 2012.

Gleisner, H., Thejll, P., Christiansen, B., and Nielsen, J. K.: Recent global warming hiatus dominated by low-latitude temperature trends in surface and troposphere data, Geophys. Res. Lett., 42, 510-517, doi:10.1002/2014GL062596, 2015.

Gorbunov, M. E., Benzon, H.-H., Jensen, A. S., Lohmann, M. S., and Nielsen, A. S.: Comparative analysis of radio occultation processing approaches based on Fourier integral operators, Radio Sci., 39, RS6004, doi:10.1029/2003RS002916, 2004.

Gramling, C.: Arctic impact, Science, 347, 818-821, doi:10.1126/science.347.6224.818, 2015.

Ho, S.-P., Hunt, D., Steiner, A. K., Mannucci, A. J., Kirchengast, G., Gleisner, H., Heise, S., von Engeln, A., Marquardt, C., Sokolovskiy, S., Schreiner, W., Scherllin-Pirscher, B., Ao, C., Wickert, J., Syndergaard, S., Lauritsen, K., Leroy, S., Kursinski, E. R., Kuo, Y.-H., Foelsche, U., Schmidt, T., and Gorbunov, M.: Reproducibility of GPS radio occultation data for climate monitoring: Profile-to-profile inter-comparison of CHAMP climate records 2002 to 2008 from six data centers, J. Geophys. Res., 117, D18111, doi:10.1029/2012JD017665, 2012.

IPCC: Climate Change 2013: The Physical Science Basis. Contribution of Working Group I to the Fifth Assessment Report of the 
Intergovernmental Panel on Climate Change, Cambridge University Press, Cambridge, United Kingdom and New York, NY, USA, 2013.

Kursinski, E. R., Hajj, G. A., Schofield, J. T., Linfield, R. P., and Hardy, K. R.: Observing Earth's atmosphere with radio occultation measurements using the Global Positioning System, J. Geophys. Res., 102, 23429-23465, doi:10.1029/97JD01569, 1997.

Lejenäs, H.: Characteristics of southern hemisphere blocking as determined from a time series of observational data, Q. J. Roy. Meteor. Soc., 110, 967-979, doi:10.1002/qj.49711046610, 1984.

Lhotka, O. and Kyselý, J.: Hot Central-European summer of 2013 in a long-term context, Int. J. Climatol., 35, 4399-4407, doi:10.1002/joc.4277, 2015.

Marques, R. d. F. C. and Rao, V. B.: Interannual variations of blockings in the southern hemisphere and their energetics, J. Geophys. Res., 105, 4625-4636, doi:10.1029/1999JD901066, 2000.

Martius, O., Polvani, L. M., and Davies, H. C.: Blocking precursors to stratospheric sudden warming events, Geophys. Res. Lett., 36, L14806, doi:10.1029/2009GL038776, 2009.

Matsueda, M.: Predictability of Euro-Russian blocking in summer of 2010, Geophys. Res. Lett., 38, L06801, doi:10.1029/2010GL046557, 2011.

Mattingly, K. S., McLeod, J. T., Knox, J. A., Shepherd, J. M., and Mote, T. L.: A climatological assessment of Greenland blocking conditions associated with the track of Hurricane Sandy and historical North Atlantic hurricanes, Int. J. Climatol., 35, 746-760, doi:10.1002/joc.4018, 2015.

Mendes, M. C. D. a., Trigo, R. M., Cavalcanti, I. F. A., and DaCamara, C. C.: Blocking Episodes in the Southern Hemisphere: Impact on the Climate of Adjacent Continental Areas, Pure Appl. Geophys., 165, 1941-1962, doi:10.1007/s00024-0080409-4, 2008.

Oliveira, F. N. M., Carvalho, L. M. V., and Ambrizzi, T.: A new climatology for Southern Hemisphere blockings in the winter and the combined effect of ENSO and SAM phases, Int. J. Climatol., 34, 1676-1692, doi:10.1002/joc.3795, 2014.

Peevey, T. R., Gille, J. C., Homeyer, C. R., and Manney, G. L.: The double tropopause and its dynamical relationship to the tropopause inversion layer in storm track regions, J. Geophys. Res., 119, 10194-10212, doi:10.1002/2014JD021808, 2014.

Pelly, J. L. and Hoskins, B. J.: A new perspective on blocking, J. Atmos. Sci., 60, 743-755, doi:10.1175/15200469(2003)060<0743:ANPOB>2.0.CO;2, 2003.

Pfahl, S., Schwierz, C., Croci-Maspoli, M., Grams, C. M., and Wernli, H.: Importance of latent heat release in ascending air streams for atmospheric blocking, Nat. Geosci., 8, 610-614, doi:10.1038/ngeo2487, 2015 .

Pirscher, B., Foelsche, U., Borsche, M., Kirchengast, G., and Kuo, Y.-H.: Analysis of migrating diurnal tides detected in FORMOSAT-3/COSMIC temperature data, J. Geophys. Res., 115, D14108, doi:10.1029/2009JD013008, 2010.

Quiroz, R. S.: The association of stratospheric warmings with tropospheric blocking, J. Geophys. Res., 91, 5277-5285, doi:10.1029/JD091iD04p05277, 1986.

Randel, W. J. and Wu, F.: Kelvin wave variability near the equatorial tropopause observed in GPS radio occultation measurements, J. Geophys. Res., 110, D03102, doi:10.1029/2004JD005006, 2005.

Randel, W. J. and Wu, F.: Variability of Zonal Mean Tropical Temperatures Derived from a Decade of GPS Radio Occulta- tion Data, J. Atmos. Sci., 72, 1261-1275, doi:10.1175/JAS-D14-0216.1, 2015.

Randel, W. J., Wu, F., and Ríos, W. R.: Thermal variability of the tropical tropopause region derived from GPS/MET observations, J. Geophys. Res., 108, 4024, doi:10.1029/2002JD002595, 2003.

Rex, D. F.: Blocking Action in the Middle Troposphere and its Effect upon Regional Climate I: An aerological study of blocking action, Tellus, 2, 196-211, doi:10.1111/j.21533490.1950.tb00331.x, 1950.

Rieckh, T., Scherllin-Pirscher, B., Ladstädter, F., and Foelsche, U.: Characteristics of tropopause parameters as observed with GPS radio occultation, Atmos. Meas. Tech., 7, 3947-3958, doi:10.5194/amt-7-3947-2014, 2014.

Scherllin-Pirscher, B., Kirchengast, G., Steiner, A. K., Kuo, Y.H., and Foelsche, U.: Quantifying uncertainty in climatological fields from GPS radio occultation: an empirical-analytical error model, Atmos. Meas. Tech., 4, 2019-2034, doi:10.5194/amt-42019-2011, 2011a.

Scherllin-Pirscher, B., Steiner, A. K., Kirchengast, G., Kuo, Y.-H., and Foelsche, U.: Empirical analysis and modeling of errors of atmospheric profiles from GPS radio occultation, Atmos. Meas. Tech., 4, 1875-1890, doi:10.5194/amt-4-1875-2011, $2011 \mathrm{~b}$.

Scherllin-Pirscher, B., Deser, C., Ho, S.-P., Chou, C., Randel, W., and Kuo, Y.-H.: The vertical and spatial structure of ENSO in the upper troposphere and lower stratosphere from GPS radio occultation measurements, Geophys. Res. Lett., 39, L20801, doi:10.1029/2012GL053071, 2012.

Scherllin-Pirscher, B., Steiner, A. K., and Kirchengast, G.: Deriving dynamics from GPS radio occultation: Three-dimensional wind fields for monitoring the climate, Geophys. Res. Lett., 41, 73677374, doi:10.1002/2014GL061524, 2014.

Scherrer, S. C., Croci-Maspoli, M., Schwierz, C., and Appenzeller, C.: Two-dimensional indices of atmospheric blocking and their statistical relationship with winter climate patterns in the Euro-Atlantic region, Int. J. Climatol., 26, 233-249, doi:10.1002/joc.1250, 2006.

Schmidt, T., Heise, S., Wickert, J., Beyerle, G., and Reigber, C.: GPS radio occultation with CHAMP and SAC-C: global monitoring of thermal tropopause parameters, Atmos. Chem. Phys., 5, 1473-1488, doi:10.5194/acp-5-1473-2005, 2005.

Schmidt, T., Wickert, J., Beyerle, G., and Heise, S.: Global tropopause height trends estimated from GPS radio occultation data, Geophys. Res. Lett., 35, L11806, doi:10.1029/2008GL034012, 2008.

Schwärz, M., Scherllin-Pirscher, B., Kirchengast, G., Schwarz, J., Ladstädter, F., Fritzer, J., and Ramsauer, J.: Multi-Mission Validation by Satellite Radio Occultation, Final report for ESA/ESRIN No. 01/2013, WEGC, University of Graz, Austria, 2013.

Schwierz, C., Croci-Maspoli, M., and Davies, H. C.: Perspicacious indicators of atmospheric blocking, Geophys. Res. Lett., 31, L06125, doi:10.1029/2003GL019341, 2004.

Shepherd, T. G.: Atmospheric circulation as a source of uncertaintyin climate change projections, Nat. Geosci., 7, 703-708, doi:10.1038/ngeo2253, 2014.

Sillmann, J., Croci-Maspoli, M., Kallache, M., and Katz, R. W.: Extreme Cold Winter Temperatures in Europe under the Influence of North Atlantic Atmospheric Blocking, J. Climate, 24, 58995913, doi:10.1175/2011JCLI4075.1, 2011. 
Steiner, A. K., Lackner, B. C., Ladstädter, F., Scherllin-Pirscher, B., Foelsche, U., and Kirchengast, G.: GPS radio occultation for climate monitoring and change detection, Radio Sci., 46, RS0D24, doi:10.1029/2010RS004614, 2011.

Steiner, A. K., Hunt, D., Ho, S.-P., Kirchengast, G., Mannucci, A. J., Scherllin-Pirscher, B., Gleisner, H., von Engeln, A., Schmidt, T., Ao, C., Leroy, S. S., Kursinski, E. R., Foelsche, U., Gorbunov, M., Heise, S., Kuo, Y.-H., Lauritsen, K. B., Marquardt, C., Rocken, C., Schreiner, W., Sokolovskiy, S., Syndergaard, S., and Wickert, J.: Quantification of structural uncertainty in climate data records from GPS radio occultation, Atmos. Chem. Phys., 13, 1469-1484, doi:10.5194/acp-13-1469-2013, 2013.

Sun, D.-Z., Zhang, T., Sun, Y., and Yu, Y.: Rectification of El Niño-Southern Oscillation into Climate Anomalies of Decadal and Longer Time Scales: Results from Rorced Ocean GCM Experiments, J. Climate, 27, 2545-2561, doi:10.1175/JCLI-D-1300390.1, 2014.

Tibaldi, S. and Molteni, F.: On the operational predictability of blocking, Tellus A, 42, 343-365, doi:10.1034/j.16000870.1990.t01-2-00003.x, 1990.

Tibaldi, S., Tosi, E., Navarra, A., and Pedulli, L.: Northern and southern hemisphere seasonal variability of blocking frequency and predictability, Mon. Weather Rev., 122, 1971-2003, doi:10.1175/1520-0493(1994)122<1971:NASHSV>2.0.CO;2, 1994.
Tsuda, T.: Characteristics of atmospheric gravity waves observed using the MU (Middle and Upper atmosphere) radar and GPS (Global Positioning System) radio occultation, P. Jpn. Acad. BPhys., 90, 12-27, 2014.

von Engeln, A., Teixeira, J., Wickert, J., and Buehler, S. A.: Using CHAMP radio occultation data to determine the top altitude of the Planetary Boundary Layer, Geophys. Res. Lett., 32, L06815, doi:10.1029/2004GL022168, 2005.

Wiedenmann, J. M., Lupo, A. R., Mokhov, I. I., and Tikhonova, E. A.: The climatology of blocking anticyclones for the northern and southern hemispheres: block intensity as a diagnostic, J. Climate, 15, 3459-3473, doi:10.1175/15200442(2002)015<3459:TCOBAF>2.0.CO;2, 2002.

Woollings, T., Charlton-Perez, A., Ineson, S., Marshall, A. G., and Masato, G.: Associations between stratospheric variability and tropospheric blocking, J. Geophys. Res., 115, D06108, doi:10.1029/2009JD012742, 2010. 